\title{
Correction \\ Correction: Furnier et al. Translating Molecular Technologies into Routine Newborn Screening Practice. Int. J. Neonatal Screen. 2020, 6, 80
}

\author{
Sarah M. Furnier ${ }^{1,2}$, Maureen S. Durkin ${ }^{1,2,3}$ and Mei W. Baker 1,2,3,4,*(D) \\ 1 Department of Population Health Sciences, University of Wisconsin School of Medicine and Public Health, \\ Madison, WI 53705, USA; furnier@wisc.edu (S.M.F.); maureen.durkin@wisc.edu (M.S.D.) \\ 2 Waisman Center, University of Wisconsin-Madison, Madison, WI 53705, USA \\ 3 Department of Pediatrics, University of Wisconsin School of Medicine and Public Health, \\ Madison, WI 53705, USA \\ 4 Wisconsin State Laboratory of Hygiene, University of Wisconsin School of Medicine and Public Health, \\ Madison, WI 53706, USA \\ * Correspondence: mei.baker@wisc.edu
}

Citation: Furnier, S.M.; Durkin, M.S. Baker, M.W. Correction: Furnier et al. Translating Molecular Technologies into Routine Newborn Screening Practice. Int. J. Neonatal Screen. 2020, 6, 80. Int. J. Neonatal Screen. 2021, 7, 66. https://doi.org/10.3390/ijns7040066

Received: 3 August 2021

Accepted: 6 August 2021

Published: 22 October 2021

Publisher's Note: MDPI stays neutral with regard to jurisdictional claims in published maps and institutional affiliations.

In the original article [1], there was a mistake in Table 2 as published. For reference Vill et al. 2019, the entry " 1 in 7096" has been corrected to " 1 in 7524". Also for reference Kay et al. 2020, the entry "No" under "SMN2 Inclusion" has been corrected to say "Realtime PCR assay to assess SMN2 copy number". The corrected Table 2 appears below. The authors apologize for any inconvenience caused and state that the scientific conclusions are unaffected. The original article has been updated. 
Table 2. Selected spinal muscular atrophy newborn screening studies.

\begin{tabular}{|c|c|c|c|c|c|c|}
\hline Reference & Region & Screening Method & SMN2 Inclusion & $\begin{array}{l}\text { Number of Newborns } \\
\text { Screened }\end{array}$ & $\begin{array}{l}\text { Reported Incidence in } \\
\text { Sample }\end{array}$ & Study Type \\
\hline Chien et al. 2017 [33] & Taiwan & $\begin{array}{c}\text { Real-time PCR SMN1 assay to } \\
\text { detect homozygous exon } 7 \text { deletion; } \\
\text { verified by droplet digital PCR } \\
\text { assay }\end{array}$ & $\begin{array}{c}\text { Droplet digital PCR assay } \\
\text { to assess SMN2 copy } \\
\text { number }\end{array}$ & 120,267 & 1 in 17,181 & Pilot \\
\hline Boemer et al. 2019 [32] & Belgium & $\begin{array}{l}\text { Real-time PCR SMN1 assay to } \\
\text { detect homozygous exon } 7 \text { deletion }\end{array}$ & No & Not applicable & Not applicable & Pilot \\
\hline Vill et al. 2019 [36] & Germany & $\begin{array}{l}\text { Real-time PCR SMN1 assay to } \\
\text { detect homozygous exon } 7 \text { deletion; } \\
\text { verified by multiplex } \\
\text { ligation-dependent probe } \\
\text { amplification (MLPA) }\end{array}$ & $\begin{array}{l}\text { MLPA to assess SMN2 } \\
\text { copy number }\end{array}$ & 165,525 & 1 in 7524 & Pilot \\
\hline $\begin{array}{l}\text { Kariyawasam et al. } \\
2020[34]\end{array}$ & Australia & $\begin{array}{l}\text { Real-time PCR SMN1 assay to } \\
\text { detect homozygous exon } 7 \text { deletion }\end{array}$ & $\begin{array}{c}\text { Droplet digital PCR assay } \\
\text { to assess SMN2 copy } \\
\text { number }\end{array}$ & 103,903 & 1 in 10,390 & Pilot \\
\hline Kay et al. 2020 [35] & New York & $\begin{array}{l}\text { Real-time PCR SMN1 assay to } \\
\text { detect homozygous exon } 7 \text { deletion }\end{array}$ & $\begin{array}{l}\text { Real-time PCR assay to } \\
\text { assess SMN2 copy number }\end{array}$ & 225,093 & 1 in 28,137 & Routine \\
\hline
\end{tabular}




\section{Reference}

1. Furnier, S.M.; Durkin, M.S.; Baker, M.W. Translating Molecular Technologies into Routine Newborn Screening Practice. Int. J. Neonatal Screen. 2020, 6, 80. [CrossRef] 